\title{
Reclaiming, Recalibrating Political and Ideological Clarity in Our Praxis
}

Susana Y. Flores, Grace Inae Blum, and Yishan Lea

Central Washington University

\begin{abstract}
Author Note
Correspondence concerning this article should be addressed to Susana Flores, School of Education, 400 E. University Way, Ellensburg, WA 98926. Email: Susana.Flores@cwu.edu
\end{abstract}




\begin{abstract}
The pandemics of COVID-19, racial injustice, and inequality have brought the country to a screeching halt. Minoritized faculty at the intersection of race, class, gender, linguistic identity, and national origin have been impacted in profound ways. The researchers here discuss the ongoing challenges using Roy's Portal metaphor and Freire's political and ideological clarity to shed light on the failure of institutions of higher learning and on the opportunities of this historical moment to reexamine and recalibrate our praxis of liberation.
\end{abstract}

Keywords: pandemic, political clarity, ideological clarity, teacher education 


\section{Reclaiming, Recalibrating Political and Ideological Clarity in Our Praxis}

We can choose to walk through it, dragging the carcasses of our prejudice and hatred, our avarice, our data banks and dead ideas, our dead rivers and smoky skies behind us. Or we can walk through lightly, with little luggage, ready to imagine another world. And ready to fight for it.

-Arundhati Roy (2020a)

Surviving the pandemic has brought us to an awareness of ideological and political clarity, taking on only what we care about in authentic ways. Being surrounded by so much death, isolation, and inequality brought us back to what really matters. Along with grief, frustration, and moments of surrender, this "pause" collectively invited the three of us to recalibrate around clarity. Through dialogue we have identified and constructed individual and shared strategies to survive and thrive where our institutions have failed. We are called to reflect on the extent in which our minoritized voices are heard in our institution's efforts at creating real, systemic, and institutional change. Freire and Bartolomé write about "political clarity" as a discursive process of our ever-deepening consciousness of the social, cultural, political, economic realities and disparities (Bartolomé,1994; Freire, 1970), while "ideological clarity" is more of an examination inward to our individual struggles, contradictions, resistance, and complicity (Bartolomé, 2000). These moments where we feel encased have drawn us to a reexamination of our critical consciousness.

As we walk through the pandemic portal (Roy, 2020a) we are left with the question of what is worth carrying with us into this world we are newly-reimagining? What are the possibilities afforded during this time? What has been revealed? What is truly necessary and what merits throwing into the refuse pile? How do we as minoritized researchers and educators narrow the focus on humanizing, fostering criticality, and on centering minoritized voices? The pandemics of Covid-19, racial injustice, and economic disparities have brought us back to a 
sense of what has always been important to us as minoritized, women of color; our focus has always been one of education for liberation. The pandemics forced us to move beyond "technical" teaching approaches towards a whole-hearted, critical consciousness, more humanizing teaching and learning with renewed ideological and political clarity.

\section{Context and Positionality}

The three researchers occupy intersectional spaces as minoritized women, transnational, and multilingual teacher educators at a rural, Historically White Institution, or HWI. Our teacher candidates identify as $90 \%$ white. One researcher identifies as a Mexican immigrant brought to the U.S. at nine years old. She is a first-generation college graduate and professor. Maintaining her native language, revitalizing some of her indigenous language, and working in an English dominant geographic area has allowed her to resist subtractive assimilation and sustain multiple cultural identities. She lives in a multigenerational home, mother of two bilinguals. She taught in a public middle school bilingual program South Central Los Angeles. She is the only Mexican, or Hispanic, in her college. Another researcher identifies as a Korean American woman. She is the daughter of Korean immigrants who came to the United States and mother to two schoolaged biracial children. Prior to her work as a teacher educator, she was an elementary school teacher having worked in both bilingual and mainstream classrooms in public schools in the greater Chicagoland and Los Angeles areas. Her primary role at the university is teaching preservice teachers at the university satellite campuses. The third researcher is of Taiwanese national origin. In the last decade and two years, the focus of her life was to survive academic scrutiny over qualifications and performance of teaching and publishing in English as a second language. Teaching and working at an HWI, we often feel minoritized and disfranchised in this institutional apparatus. Our identities and subjectivities inform our praxis. 


\section{Renewal/Refocus "Ideological Clarity" in Teacher Education}

The pandemic revealed the many ways in which our minoritized voices have not substantively mattered to our HWI. The HWI has student-facing performative ethic of care and emphasis on well-being and mental health, urgent and necessary, but there has been no such urgency for the well-being and mental health of staff and faculty. The things that we celebrate are not the things that make us human. What does the HWI celebrate? Change? Transformation, or the mediocrity and the status quo? There's a complacency in the mediocrity, in resting in place, the repose of tradition. It's easier to be complacent. The curriculum and technical approaches to teaching do not work for minoritized people. This pandemic has revealed what Roy has termed "the rupture." This social, economic, and political rupture is an instantaneous boundary between the slipping and locked parts of a fault during an earthquake; between those with power and access and those without. There are those locked parts of a bureaucratic and fragmented society that yearn to return to normal or to a "new normal." We reject this call to return to normal. This rupture is an opportunity to rethink our complicity and the corruption of the curriculum, the carcasses, and staid methodologies. This rupture doesn't fit any prescribed rubric, nor will it lie down with what the institution values performatively. The "new normal" doesn't value authentic caring nor its concomitant emotional labor. This rupture and Roy's portal force us to make intentional decisions about the praxis we choose to carry with us knowing it/they will not bolster standardized test scores, accreditation, or the performative work of donothing diversity and equity committees.

\section{Implications}

In our collective turn away from the return to normalcy, we hold to the following principles to guide our turn towards praxis informed by the political and ideological clarity 
surfaced through the pandemic. While we work in teacher education, and co-teach in Secondary STEM education, we suggest colleagues across the disciplines, including STEM, consider these principles as a way to consider their own political and ideological clarity about the work we do and our efforts toward institutional transformation.

1. Creating Humanizing Spaces: Working towards and within humanizing spaces that we need, we believe in, and where we can practice critical consciousness and push back. As minoritized teacher educators, we commit to creating spaces in our classrooms to ask questions to have difficult conversations - i.e. activities to discuss how to manage stress, writing for five minutes and reiterating to our students that these are not normal times.

2. Finding "your people": Learning from and with practitioners and scholars who are engaged with critical, culturally sustaining transformative work. Because of the pandemic, so much is available and accessible for free. We can learn from scholars who are doing this work and generously sharing their work publicly such as the \#disrupttexts, \#educolor movements.

3. Resisting the metrics, measures, and rubrics: Choosing to resist the traditional metrics, measures, and rubrics that define our work in de-humanizing ways. Working towards creating learning environments in which we act against perpetuating the same demoralizing practices and policies with our students.

4. Creating, collaborating, co-constructing: Working together with critically conscious colleagues in teaching and scholarship in projects that work to sustain us despite the dehumanizing contexts in which we work which often devalue our contribution. 


\section{Conclusion}

As Roy (2020b) suggests we are choosing to leave stale practices, bankrupt theories, and bureaucratic baggage behind, and "in the midst of this terrible despair, it offers us a chance to rethink the doomsday machine we have built for ourselves. Nothing could be worse than a return to normality" (Roy 2020a). This pandemic has caused us, through reflection and inquiry, to refocus on what was always important in teacher education: humanizing relationships, humanizing pedagogies, transformative theories, and culturally sustaining pedagogies. We are choosing to walk through the pandemic portal and starting anew. We are walking through this pandemic portal ahead of our institution and continue to speak and advocate for structural change. We have learned that our voices and polite requests made through our institution's annual "listening sessions" and through tokenized representation in department, college, and university wide Diversity, Equity, and Inclusion Committees are listened to, transcribed, and included in multiple reports but have not resulted in the structural changes that this historical moment calls for. We, three minoritized faculty, are now creating a more concerted transdisciplinary collective comprised of faculty and staff that is in solidarity with AsianAmerican, Pacific Islanders, Black Latinx, and LGBT colleagues, and other minoritized communities and we are making demands of the institution, outside of the constraint of DEI Committees. These demands are for education for liberation that fosters critical consciousness and humanizing teaching and learning with ideological and political clarity. 


\section{References}

Bartolomé, L. I. (2004). Critical pedagogy and teacher education: Radicalizing prospective teachers. Teacher education quarterly, 31(1), 97-122.

Bartolomé, L. I. (2000). Democratizing bilingualism: The role of critical teacher education. Lifting every voice: Pedagogy and politics of bilingualism, 167-186.

Cobley, C. and Jansz, L. (2003). Introducing semiotics. UK: Totem Books.

Ebarvia, T., Germán, L., Parker,K.N., and Torres, J. (2020, November 19). \#DisruptTexts. https://disrupttexts.org/

Freire, P. (1970). Cultural action and conscientization. Harvard Educational Review, 40(3), 452-477.

Freire, P. (2017) Pedagogy of the oppressed. New York, NY: Bloombury Publishing

Guerra (2006) Identity, aesthetics, objects. Journal of Aesthetic Education, 40 (4), $65-76$.

Roy, A. (2020a). Arundhati Roy: 'The pandemic is a portal'. Financial Times, 3.

Roy, A. (2020b). Azadi: Freedom. Fascism. Fiction. Chicago; Haymarket.

U.S.G.S. Earthquake Glossary. https://earthquake.usgs.gov/learn/glossary/?term=rupture $\% 20$ front

Winnicott, D. W. (1971). The use of an object and relating through identifications. Playing and reality. 